\title{
Linings of agglutinated Foraminifera from the Devonian: taxonomic and biostratigraphic implications.
}

\author{
K. N. BELL \& T. M. WINCHESTER-SEETO \\ Centre for Ecostratigraphy and Palaeobiology, Department of Earth and Planetary Sciences, Macquarie University, Sydney, 2109, Australia.
}

\begin{abstract}
The organic linings of agglutinated foraminiferans from the Devonian are documented and described. These linings have been recovered in palynological residues from Australia, France, Pakistan and Siberia and range from the Lochkovian to the Frasnian. Six species are described as new: Hemisphaerammina coolamon, Psammosphaera garraay, Reophanus proavitus, Saccammina mea, Saccammina wingarri and Thurammina mirrka. Three species, with a wide geographical spread and a relatively limited stratigraphic range, may prove to have some utility in intercontinental correlation: Inauris tubulata Conkin \& Conkin, Saccammina mea n. sp. and Saccammina wingarri n. sp. J. Micropalaeontol. 18(1): 27 43, June 1999.
\end{abstract}

\section{INTRODUCTION}

The organic linings of rotalid foraminifera from the Permian to the Recent are well documented (Stancliffe, 1989), but only recently have linings of Palaeozoic agglutinated foraminifera been reported (Winchester-Seeto \& Bell, 1994). Continuing study of material from Australia, France, Siberia and Pakistan has shown that Ordovician to Upper Devonian agglutinated foraminiferal organic linings are commonly present in shallow marine limestones, marls and shales. In earlier works reporting organic linings they have been referred to as microforaminifera because of their small size (typically $<200 \mu \mathrm{m}$ ). We believe that such a term is unwarranted as foraminifera are now known to form part of the sub-63 $\mu \mathrm{m}$ fauna (Gooday, 1986a, b; Pawlows$\mathrm{ki}, 1991)$ and Burnett (1979) refers to foraminifera of the 10$15 \mu \mathrm{m}$ range; thus these smaller forms are part of the entire foraminiferan size range (albeit a size range seldom studied) and require no special name.

Apart from the Allogromiidae, the various foraminiferal genera are defined as either agglutinate or calcareous. Bender (1995) has shown that most agglutinated genera have an inner organic lining and our specimens are obviously congeneric with described agglutinated genera, but do not have any agglutinant covering. This absence of outer wall material may be an environmental response, or just a preservational or procedural artefact. At present we cannot differentiate between these possibilities, so we prefer to use established genera and to ignore the absence of agglutinating wall material. Hohenneger (1990) has suggested that the Allogromiidae and simple Astrorhizidae (in which our specimens are classified) may be more closely related than previously thought and that the amount of agglutinated material present may have little significance and even be environmentally controlled; our studies support this view.

The purpose of this study is to describe and document the inner, organic linings of agglutinated foraminifera, recovered in palynological processing of Devonian material, and to examine their taxonomic and biostratigraphic implications. In particular, we aim to place the species recovered into a more tightly constrained time-frame than most previous studies by referring to the conodont zones from which they were recovered.

\section{METHODS}

The foraminiferal linings described in this study were recovered from samples processed in the quest for chitinozoans, thus the criterion for the selection of sections was the prospectivity for acid-resistant fossils. Many of the sections had also previously yielded conodonts, and strong, reliable stratigraphic control is already in place. Samples yielding foraminiferal linings are exclusively from marine strata, dominantly shallow marine limestones and shales.

Processing methods followed those outlined by Paris (1981), including initial treatment of $50 \mathrm{~g}$ of crushed rock with $10 \% \mathrm{HCl}$ until all the carbonate had been dissolved. This is followed by acid digestion in $50-70 \% \mathrm{HF}$ for 1-4 days. Nitric acid (concentrated) was used when necessary for surface etching, the dissolution of fluorite salts and the destruction of amorphous organic matter. The residue was then separated through a $53 \mu \mathrm{m}$ sieve and the coarse fraction was picked with a micropipette. Well-preserved specimens were selected for examination by conventional scanning electron microscopy or with an environmental electroscanner; the advantages of the environmental electroscanner have been outlined by WinchesterSeeto (1993a).

\section{LOCALITY INFORMATION \\ Early Devonian}

The majority of foraminiferal linings were recovered from Lower Devonian sequences spanning the Lochkovian-Pragian boundary (i.e. pesavis-sulcatus conodont zones); this is primarily due to the more intensive nature of the chitinozoan and conodont work undertaken on these areas.

The Garra Limestone, near Wellington, central New South Wales (Figs 1 and 2), yielded the most specimens. It is characterized by grey to dark grey, highly fossiliferous limestones from a subtidal, shallow shelf. Studies of conodonts (Wilson, 1989) and chitinozoans (Winchester-Seeto, 1993b) provide a detailed biozonation for sections MUNG, RUN (pesavis Conodont Zone) and GCR (pesavis-sulcatus conodont zones). A section through the Martins Well Limestone Member of the Shield Creek Formation (MW) from the Broken River area of northern Queensland has been dated as spanning the pesavis-sulcatus conodont zones (Benson \& Bear in Mawson et $a l ., 1988$ ), although all foraminiferal linings were recovered from the sulcatus Zone. This limestone is a shallow marine bioclastic calcarenite deposited on a broad, stable shelf (for further details see Wyatt \& Jell, 1980; Winchester-Seeto, 1993c). 


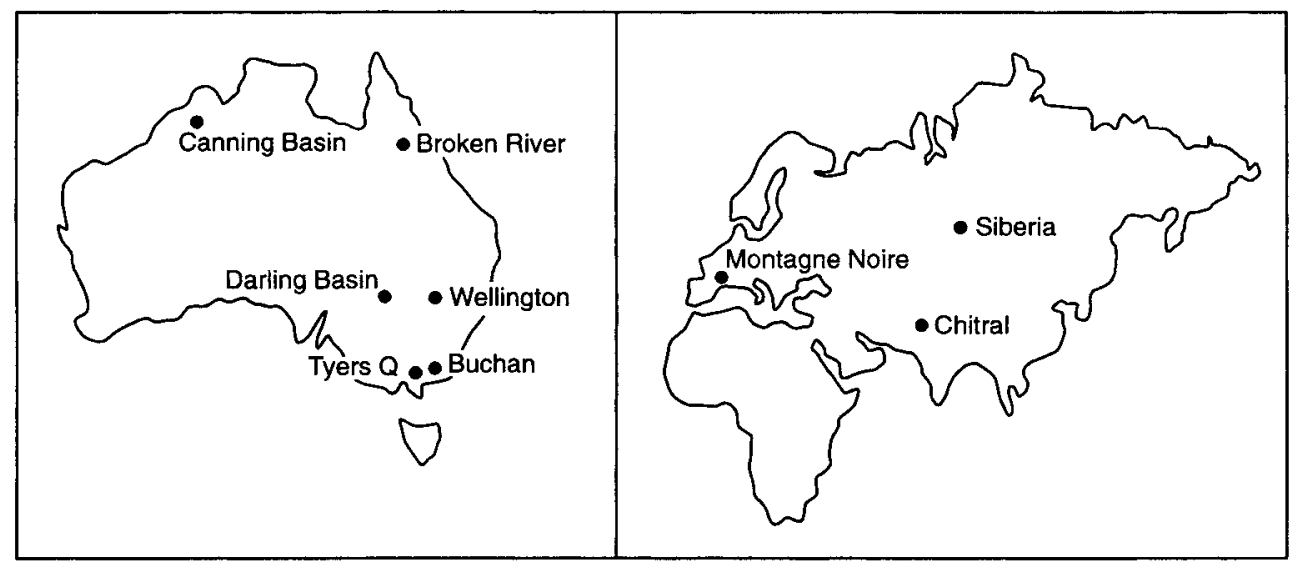

Fig. 1. Maps showing general position of localities investigated in this study.

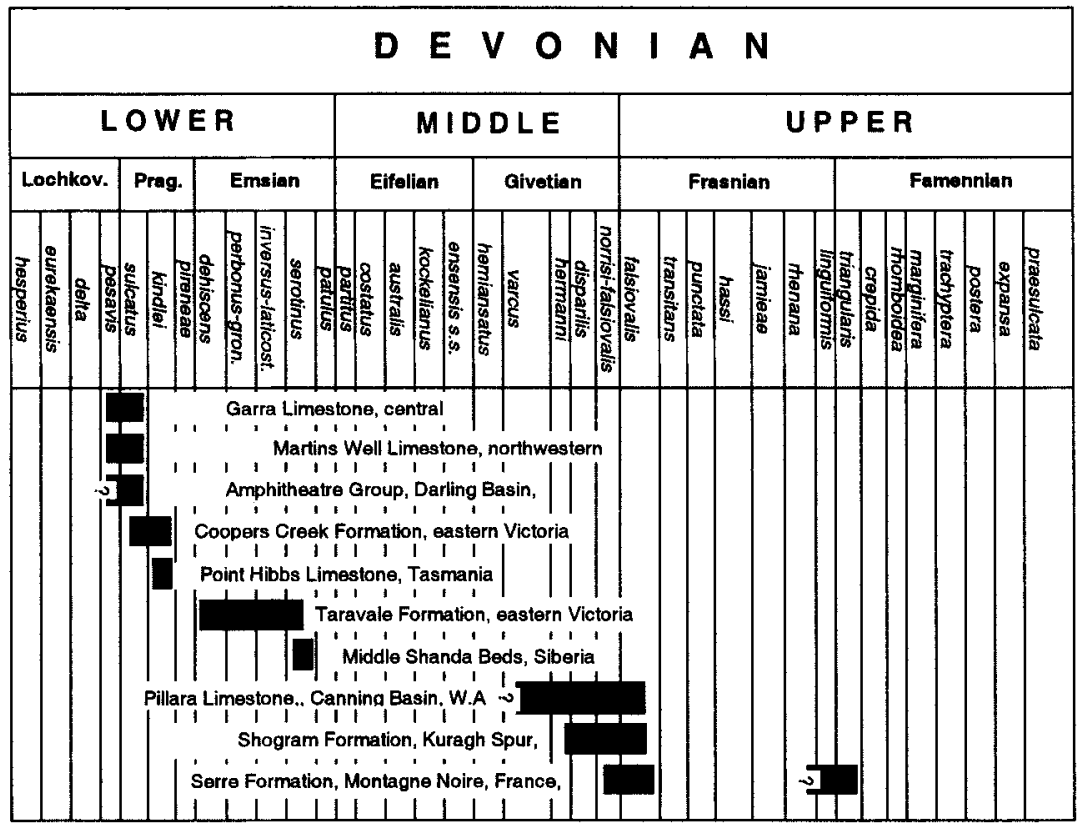

Fig. 2. Stratigraphic chart showing range of sections/bores detailed in this study, related to conodont zones.

The Amphitheatre Group from the Darling Basin, western New South Wales, represented in the Kewell East bore-core (KE DDH1), yielded a moderate diversity of foraminiferal linings. The interbedded grey to dark grey claystones, carbonaceous shales and siltstones represent a marine environment, possibly a transgressive sequence (Bembrick, 1997). Chitinozoan evidence suggests a Late Lochkovian-Early Pragian age (no younger than sulcatus Conodont Zone; Winchester-Seeto, unpubished data).

Pragian faunas were recovered from the Tyers and Boola quarries (Tyers, BOO) in the limestones of the Coopers Creek Formation, eastern Victoria. Conodonts date the two sections as spanning the sulcatus-kindlei conodont zones (Mawson \& Talent, 1994) and chitinozoans included Bulbochitina bulbosa, an important zone fossil (Winchester-Seeto, 1993c). Palaeoen- vironmental interpretation of the area is controversial (see Rehfisch \& Webb, 1993; Mawson \& Talent, 1994).

Fossiliferous lime packstone characterizes the Point Hibbs Limestone, from Sanctuary Bay in southwestern Tasmania (Carey \& Berry, 1988). The Sanctuary Bay section spans the sulcatus-kindlei conodont zones (Philip \& Pedder, 1968; Winchester-Seeto, unpublished data).

The Taravale Formation, Buchan Group, from eastern Victoria, yielded a moderate number of Emsian foraminiferal linings. The section along the Gelantipy Road (Gel. Rd.) extends from the dehiscens to the serotinus conodont zones (Mawson, 1987; Winchester-Seeto, 1996). The succession consists of nodular limestones, shales and impure limestones, probably deposited on a broad, gently sloping marine shelf 
(Talent, 1965; 1969).

The Shanda horizons are situated on the southwestern margin of the Kuznetsk Basin in southern Siberia. Samples of the Middle Shanda beds (MSh) were collected from the southeastern wall of the Akaratchkino Quarry (section B-8313 of Yolkin et al., 1988). The Middle Shanda strata are massive, light coloured limestones interbedded with minor shales and lie within the serotinus Conodont Zone.

\section{Middle and Late Devonian}

A series of spot samples from the cores through strata in the Canning Basin, Western Australia, were investigated for palynomorphs. One sample from bore-core PD 166, depth $358.4 \mathrm{~m}$, from the Pillara Limestone, Unit 1 (BHP log units), yielded one species of foramininferal lining. The age is inferred to be middle Givetian, ?varcus Conodont Zone (Colbath, 1990; Winchester-Seeto \& Paris, 1995).

Situated within the Hindu Kush, the Kuragh spur is located in the Chitral region of northwest Pakistan. The Shogram Formation outcrops along the spur as $100 \mathrm{~m}$ of limestones, sandstones and calcareous shales. Two samples from a section through this formation yielded palynomorphs; KG sample 1 is dated as ?Late hermanni Conodont Zone, i.e. Late Givetian, and KG sample 17 is from the ?Late falsiovalis Conodont Zone, i.e. Early Frasnian (Molloy, 1979; Winchester-Seeto \& Paris, 1995).

Extensive biostratigraphic work has been carried out on two sections from the Serre Formation in the Montagne Noire, southern France (e.g. Klapper \& Feist, 1985; Klapper, 1988; Winchester-Seeto \& Paris, 1995). The oldest segment of the formation is represented by a trench through the lower part of the Serre Formation (La Serre trench A; LSA) and has been dated as spanning the Middle-Late Devonian interval, i.e. norrisi-falsiovalis Conodont Zone to falsiovalis Conodont Zone. Trench C (LSC) extends across the Frasnian-Famennian boundary (?linguiformis-triangularis conodont zones).

\section{GENERAL RESULTS}

Our studies, so far, indicate that the organic linings of agglutinated foraminifera are fairly widespread both geographically and chronologically. Diverse faunas have been recovered (by palynological processing) from shallow marine environments such as limestones, marls and shales from Ordovician to Late Devonian in age and in localities on three continents (see locality data). Although usually not of great abundance (about 10 per $50 \mathrm{~g}$ rock sample), they are found in about $50 \%$ of samples processed. We have found six of the agglutinate families known from this time span, 12 known genera (plus one indeterminate), of which only two (Hemisphaerammina and Tolypammina) are of attached genera (the others having free tests) and 24 species - six of established species, seven compared with known species, six new species and five left in open nomenclature because of a lack of specimens.

Tubular linings with thin and thick walls are present in many samples from a variety of localities, and may represent broken parts of various genera such as Hyperammina, Rhabdammina or Saccorhiza, or may even be Allogromiidae such as Shepherdella, but cannot be further determined and are thus left off faunal lists.

Most of the specimens are highly thermally mature; they are black and many specimens are broken or compressed - this may have affected our recovery rates and introduced bias in the types of genera and species preserved. Until comparable work is undertaken in other parts of the world on a wider suite of sediment types, little can be further deduced.

The surface of the organic wall may be either smooth or show varying degrees of reticulation, i.e. raised ridges outlining smaller or larger smooth areas. These ridges, we believe, are indications of the outlines of the agglutinate material used in an outer wall, but since lost either by diagenesis or treatment. Those specimens with smooth, unridged surfaces probably had either no agglutinated outer wall or one in which the various grains were sparse and perhaps only very weakly attached. It is well known that some species of foraminiferans show a high degree of grain size selectivity (Heron-Allen, 1915; Petelin, 1970; Bender, 1995; Scott et al., 1998). Thus these species would show fairly uniform reticulations on the outer surface of the organic lining. That the surface of the lining may, however, show differing sizes of reticulations is also consistent with the results of Allen et al. (1998), who have found that several agglutinate species show fractal (i.e. self-similar) grain distribution in the test wall. The study of these aspects of foraminiferan test structure is just in its infancy and how, or if, they may be applied to fossil assemblages lies in the future.

Thin sections of the sampled limestones and shales have proved of little use; the 'normal' foraminiferans are very rare and seldom found in thin section; and those that have been seen have no organic layer present, most likely due to the diagenetic changes in the often partly recrystallized sediments. Both Hedley (1962) and Bender (1995) have commented on the rapid shrinkage and decay of the inner organic lining upon death of a foraminiferan.

\section{DISCUSSION}

\section{Taxonomic considerations}

Many species show a variety of 'holes' in the surface of the lining; these are dominantly apertures or pores, but may also be due to breakages caused by diagenesis or in extraction procedures. The occurrence of the main aperture(s) (of the order of $10 \mu \mathrm{m}$ ) for species such as Saccammina and Thurammina is easily determined either by size and/or position on a neck or protuberance. Close examination of the test wall, however, shows the presence, quite often, of smaller openings (Plate 1, fig 6); these holes, usually $1-5 \mu \mathrm{m}$ in diameter, are termed pores. The smooth walled species do not have such pores present. Within any one species the pores appear to be of relatively constant size and numbers, but differences occur between species, and is carried to an extreme case in Gen. et sp. indet. (Plate 1, figs 12 and 13) in which the test is heavily perforated. We are not aware of any previous mention of such pores in the test wall of allogromiids. It is also possible that the pores are due to some form of chemical degradation of the test during diagenesis or in the processing of the sediments, or due to boring by parasites or predators.

The various genera can be subdivided into morphological groups (i.e. into species) based on characters such as shape, surface structures, wall thickness, number of apertures, all of which have previously been accepted as specific characters for normal-sized foraminiferans. Figure 3 lists the features used in 


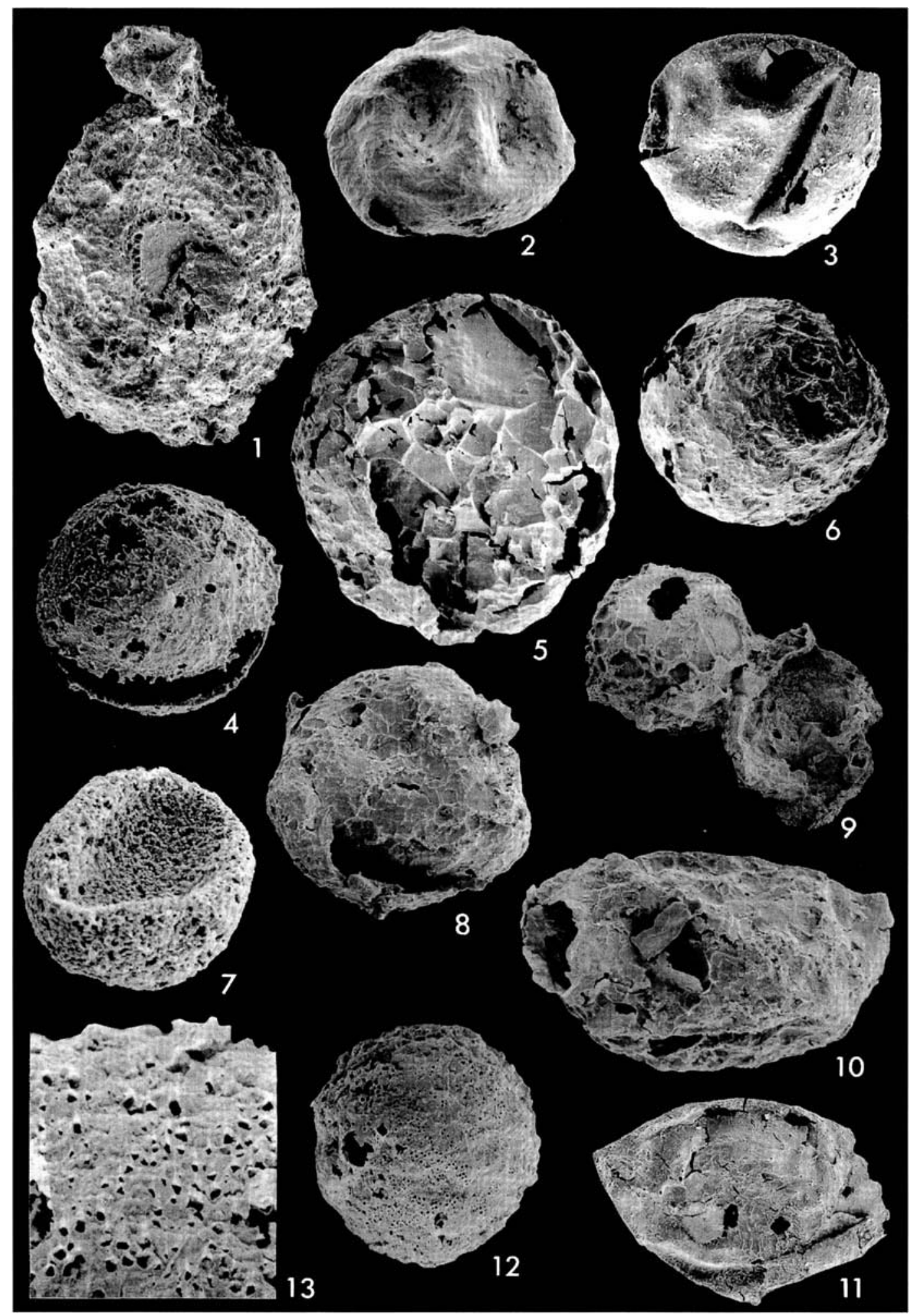

Explanation of Plate 1

fig.1. Inaurus tubulata Conkin, Conkin \& Thurman, 1979, AMF102639, MSh. 1, $\times 300$. figs 2, 3. Psammosphaera cava Moreman, 1930: fig. 2, AMF102640, GCR 37, $\times 300$; fig. 3, AMF102641, GCR 117.3, $\times 450$. figs. 4-6, 8. Psammosphaera garraay sp. nov.: fig. 4, paratype, AMF102642, GCR 37, $\times 400$; fig. 5, paratype, AMF102643, RUN 76.6, $\times 350$; fig. 6, paratype, AMF102644, GCR 605, $\times 400$; fig. 8, paratype, AMF102646, MUNG 24.8, $\times 400$. fig. 7. Psammosphaera sp., AMF102645, MUNG 76.2, ×400. fig. 9. Sorosphaera sp. cf. S. confusa Brady, 1879, AMF102647, Gel. Rd. 11T/81.7, $\times 300$. figs. 10, 11 . Amphitremoida sp. cf. A. citroniforma Eisenack, 1938: fig. 10, AMF102649, MUNG 24.8, $\times 400 ;$ fig. 11, AMF102648, KG $1 \times 150$. figs 12, 13. Gen. et sp. indet.; fig. 12, AMF102682, 16T/65.0, $\times 450$; fig. 13, enlargement of fig. 12, $\times 2000$. See text for abbreviations. 


\begin{tabular}{|l|l|}
\hline \multicolumn{1}{|c|}{ Genus } & \multicolumn{1}{|c|}{ Criteria for species determination } \\
\hline Psammosphaera & $\begin{array}{l}\text { size of test } \\
\text { wall texture (smooth or reticulate) }\end{array}$ \\
\hline Thurammina & $\begin{array}{l}\text { number of apertures } \\
\text { whether apertures are raised, or flush with the surface }\end{array}$ \\
\hline Saccammina & $\begin{array}{l}\text { wall texture (smooth or reticulate) } \\
\text { whether apertures are raised, or flush with the surface }\end{array}$ \\
\hline Hemisphaerammina & $\begin{array}{l}\text { wall texture (smooth or reticulate) } \\
\text { presence/absence of basal flange }\end{array}$ \\
\hline
\end{tabular}

Fig. 3. Criteria for determination of species.

this paper for specific separation. Saccammina, as defined by Loeblich \& Tappan (1988) has a single aperture raised and on a long or short neck; here, however, we follow Hedley (1962) and Holbourn \& Kaminski (1995), including within this genus forms with a single, round aperture, apparently flush with the surface, as well as forms with a raised aperture. Multi-apertured forms, either raised or flush with the test wall, are placed in Thurammina. It may be that species with apertures raised on necks or papillae could have the opening(s) in the organic lining either raised or flush; studies on recent material do not elucidate this question.

\section{Biostratigraphic implications}

There have been few attempts to use Palaeozoic agglutinate foraminiferans for biostratigraphic correlation. This is due to a variety of factors, including the small number of studies globally, poor stratigraphic control of the material studied, and the problems involved in differentiating species when the forms are simple.

Of the 24 species identified in this study, eight, so far, are only known from one region of Australia; a further nine species, however, occur in areas of Australia separated by hundreds of kilometres (e.g. Sorosphaera sp. cf. S. confusa Brady, Tolypammina tantula Bell and Saccammina sp. are found in central New South Wales and in Victoria) or separated by thousands of kilometres (e.g. Psammosphaera garraay $\mathrm{n}$. sp., Saccammina mea n. sp., Thurammina sp. cf. T. subspherica Moreman and Hemisphaerammina collamon $\mathrm{n}$. sp. are found in central New South Wales and in north Queensland; Hyperammina devoniana Crespin has been observed from central New South Wales, north Queensland and Western Australia; Hyperammina sp. cf. H. sappingtonensis Gutschick has been found in central New South Wales, north Queensland and Tasmania). Eight species also occur on two or more continents: Psammosphaera cava Moreman has been found in Australia, North America, Great Britain, Austria and Sardinia; Psammosphaera sp. occurs in Australia and Siberia; Amphitremoidea sp. cf. A. citroniforma Eisenack has a disjunct range and occurs in Australia and Pakistan; Lagenammina ovata Bell has been recovered from Australia and Pakistan; Saccammina mea n. sp. is found in Australia and Siberia; Saccammina wingarri $\mathrm{n}$. sp. occurs in Western Australia and southern France; Webbinelloidea similis Stewart \& Lampe is found in Australia, Poland and the UStA, and Hyperammina sp. cf. H. sappingtonensis has been recovered from Australia and Siberia.
Three species may have biostratigraphic utility globally, albeit only in a broad sense, namely: Inauris tubulata Conkin \& Conkin (serotinus-costatus conodont zones), Saccammina mea $\mathrm{n}$. sp. (pesavis-serotinus conodont zones) and Saccammina wingarri n. sp. (varcus-falsiovalis conodont zones).

Within Australia, Sorosphaera sp. cf. S. confusa, Hemisphaerammina coolamon n. sp., Psammosphaera garraay n. sp. and Thurammina sp. cf. T. subspherica Moreman appear to be restricted to the pesavis-sulcatus conodont zones, while Hyperammina sp. cf. $H$. sappingtonensis ranges through the pesavisserotinus conodont zones, and Tolypammina tantula spans the pesavis-perbonus conodont zones. Further studies are needed to confirm the full ranges of these species.

There are a number of very long ranging species or ones with disjunct, long ranges: Webinellinoidea similis, Hyperammina devoniana, Amphitremoidea sp. cf. A. citriniforma, Lagenammina ovata and Psammosphaera cava (Fig. 4). This list highlights the problems associated with determining species in organisms with a very simple morphology, and may limit the utility of some foraminifera species for biostratigraphy.

\section{SYSTEMATIC DESCRIPTIONS}

All figured and type specimens are lodged with the Australian Museum, Sydney, Australia, and are labelled with numbers prefixed with AMF.

Taxonomic conventions used in this study follow Loeblich \& Tappan (1988).

Order Foraminiferida Eichwald, 1830

Suborder Textulariina Delage \& Hérouard, 1896

Superfamily Astrorhizacea Brady, 1881

Family Astrorhizidae Brady, 1881

Genus Inauris Conkin, Conkin \& Thurman, 1979

Type species. Inauris tubulata Conkin, Conkin \& Thurman, 1979 Inauris tubulata Conkin, Conkin \& Thurman, 1979

(Plate 1, fig. 1)

1979 Inauris tubulata Conkin, Conkin \& Thurman: 4, plate 1, figs $1-10$.

Material. One specimen from MSh (sample 4).

Distribution. Middle Shanda Beds, Siberia, serotinus Conodont Zone; Jeffersonville Limestone, Kentucky, USA, Late Emsianmid-Eifelian.

Description. Test free; a ring-like, undivided tubular chamber; wall reticulate; aperture rounded produced on a short neck; the inner central area covered by a thin membraneous sheet (after Loeblich \& Tappan, 1988).

Dimensions. Length, $125 \mu \mathrm{m}$; diameter, $80 \mu \mathrm{m}$.

Remarks. Originally described from Kentucky, USA (Conkin $e t$ al., 1979), this is the only record of it outside the type locality or as a foraminiferal lining. Loeblich \& Tappan (1988) postulated a membraneous central area for Inauris and our specimen clearly shows such an inner membrane apparently attached to the outer 'ring' by digitate processes.

Family Psammosphaeridae Haeckel, 1894 Genus Psammosphaera Schulze, 1875 


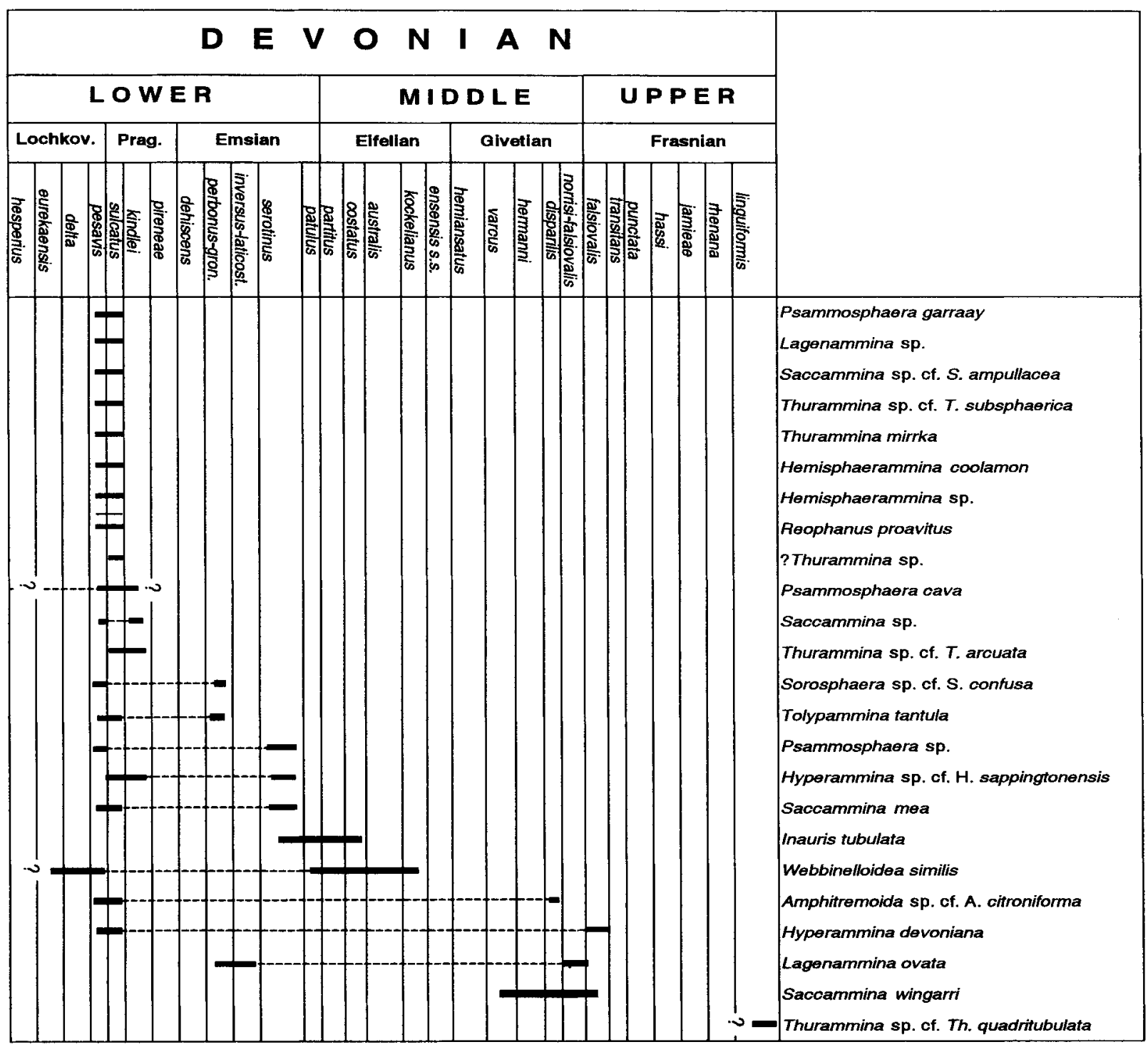

Fig. 4. Ranges of identified foraminifera, based on our studies and a literature search.

Type species. Psammosphaera fusca Schulze, 1875 Remarks. The differentiation of species within Psammosphaera has been based on the size and/or the coarseness of the test wall (Moreman, 1930; Dunn, 1942; Mound, 1968), although varying wall thickness, test size and the grain size used were not considered to be reliable indicators for specific diagnoses of such simple organisms by Browne \& Schott (1963) or McClellan (1966). We consider that the smoothness or otherwise of the organic lining surface can be used as a diagnostic feature as an indicator of the original wall texture. Loeblich \& Tappan (1988: 28) state that Psammosphaera has no inner lining, but Bender (1995) found that $P$. fusca had an inner organic lining; the presence of reticulate ridges on some individuals suggests that originally these specimens had an agglutinated outer test. A number of specimens of each of the species described here show equatorial splitting into two equal halves which, although, looking like Hemisphaerammina, may be differentiated by their very much thinner wall and rough-edged sutural boundary. Psammosphaera cava Moreman, 1930

(Plate 1, figs 2 and 3)

1930 Psammosphaera cava Moreman: 48, plate 6, fig. 12.

1942 Psammosphaera cava Moreman; Dunn: 322, plate 42, fig. 6.

1985 Psammosphaera cava Moreman; Gnoli \& Serpagli: 214, plate 1, figs. 19, 20.

1994 Psammosphaera spp. Winchester-Seeto \& Bell: 202, figs 2.7, 2.9. 2.14; non 2.8, 2.10, 2.12 .

1996 Psammosphaera cava Moreman; Bell: 88, fig. 6J.

Material. Fifteen specimens from GCR (samples 37, 50.2, 117.3, 479.6, 605); RUN (samples 44.4, 199.3), Tyers Q (sample from 'Far end'), MW (sample 13.7, 31), KE (samples 511, 669.8, 791.9). 
Distribution. Garra Limestone, Wellington, NSW, pesavissulcatus conodont zones; Amphitheatre Group, Darling Basin, NSW, pesavis - sulcatus conodont zones; Martins Well Limestone, Broken R, Queensland, sulcatus Conodont Zone; Coopers Creek Formation, Victoria, kindlei Conodont Zone; Sardinia, Upper Pridolian, eosteinhornensis Conodont Zone to Early Lochkovian; basal Niagaran, Silurian, Missouri, USA.

Dimensions. Diameter, 69-140 $\mu \mathrm{m}$ (av. $97 \mu \mathrm{m}$ for nine specimens)

Remarks. Psammosphaera cava is a very simple foraminiferan; the shape may vary from globular to slightly ovate, but this is not a preservational effect. The smooth surface suggests that either the living animal did not have any agglutinate coating, or that any grains were not strongly attached, or that the test wall was made of small grains, as described by Moreman (1930).

Psammosphaera cava has been recovered from the pesavissulcatus conodont zones in Victoria (Bell, 1996) and the specimens recovered in this study fit into the size ranges previously observed. A range of variation of preservational styles can be observed, including a worn and somewhat 'lumpy' surface (Plate 1, fig. 3) and a slightly pitted surface (Plate 1, fig. 2).

Psammosphaera cava has a very long stratigraphic range and it may well be that several species are being confused. It is reported from the middle Ordovician (Gutschick, 1986), through the Silurian (Eisenack, 1932; Stewart \& Priddy, 1941; Browne \& Schott, 1963; McClellan, 1966; Kristan-Tollmann, 1971b; Mabillard \& Aldridge, 1982) and into the Devonian (Gnoli \& Serpagli, 1985; Bell, 1996) and perhaps into the Upper Carboniferous (Pennsylvanian) as $P$. gracilis Ireland (Toomey, 1974) [Mound (1968) and Kristan-Tollmann (1971b) synonymized gracilis with cava]. Browne \& Schott (1963) and KristanTollmann (1971b) give extensive synonymies for this species.

\section{Psammosphaera garraay n. sp.}

(Plate 1, figs 4-6, 8)

1994 Psammosphaera spp. Winchester-Seeto \& Bell: 202, figs 2.8, 2.10, 2.12; non 2.7, 2.9. 2.14.

Derivation of name. From the Australian Aboriginal word garraay, meaning sandhill, referring to the type locality in the Garra Limestone (Wiradjuri language).

Diagnosis. A species of Psammosphaera represented by an organic lining with a reticulated wall.

Holotype. AMF87212, Fig. 2.8 Winchester-Seeto \& Bell (1994: 202).

Material. Thirteen specimens from RUN (samples 44.4, 76.7), MUNG (samples 24.8, 71.5), GCR (samples 37, 343, 401.8), MW (samples 31, 95.6).

Type locality and horizon. RUN 44.4, $42.2 \mathrm{~m}$ above the base of the RUN section of the Garra Limestone, central NSW, Australia.

Description. Test free; globular; organic foraminiferal lining, wall reticulated; no apparent apertures.

Distribution. Garra Limestone, Wellington, NSW, pesavissulcatus conodont zones; Martins Well Limestone, Broken River area, Queensland, sulcatus Conodont Zone.

Dimensions. Diameter, 71-144 $\mu \mathrm{m}$ (ave. $97 \mu \mathrm{m}$ for 12 specimens).
Remarks. This species is easily separated from Psammosphaera cava by its reticulate surface (i.e. numerous raised ribs outlining various sized small areas). These raised ribs possibly represent the boundaries of the various sized sand grains that may have once covered the test and have now been lost by some cause (preservational or procedural) not yet understood. The size ranges of $P$. cava and $P$ sammosphaera garraay are the same.

Numerous specimens of $P$. garraay show a partial equatorial 'tear'. This may be actual splitting or only an attachment scar similar to that seen in the Recent $P$. fusca Schulze.

\section{Psammosphaera sp.}

(Plate 1, fig. 7)

Material. Two specimens from MUNG (sample 76.2) and MSh (sample).

Distribution. Garra Limestone, Wellington, NSW, pesavis Conodont Zone; Middle Shanda Beds, Siberia, serotinus Conodont Zone.

Description. Test free; an organic foraminiferal lining; globular; surface has a 'shaggy' appearance due to relatively high, narrow, closest rounded ridges; no apparent aperture.

Dimensions. Diameter of chamber, 76-79 $\mu \mathrm{m}$.

Remarks. Psammosphaera sp. is easily distinguished from other species of this genus by the unusual surface, which resembles a 'shaggy' carpet. This is probably a new species, but has been left in open nomenclature pending the discovery of more specimens.

Genus Sorosphaera Brady, 1879

Type species. Sorosphaera confusa Brady, 1879

Sorosphaera sp. cf. S. confusa Brady, 1879

(Plate 1, fig. 9)

1994 ?Sorosphaera sp. Winchester-Seeto \& Bell: 202, fig. 2.6.

Material. Two specimens from MUNG (sample 76.2) and Gel. Rd. (sample 11T/81.7).

Distribution. Garra Limestone, Wellington, NSW, pesavis Conodont Zone; Taravale Formation, Victoria, perbonus Conodont Zone.

Description. Test free; subglobular chambers joined together without definite arrangement; no apparent aperture; wall reticulate.

Dimensions. Diameter of chamber $1,84.4 \mu \mathrm{m}$; diameter of chamber 2, 80-89 $\mu \mathrm{m}$.

Remarks. Before the Kristann-Tollmann (1971a) revision of the early Palaeozoic sorosphaerid foraminifera, many species had been erected based only on the number of chambers in the attached masses. Kristan-Tollmann (1971a) showed that using only the arrangement of chambers (planar or three-dimensional), five species could be distinguished. However, in the studies of normal-sized agglutinate foraminiferans in Devonian sediments from eastern Australia, the classification proposed by Kristan-Tollmann (1971a) is not useful; within any one sample, various groupings of chambers can occur and merge from one form to another, and to suggest that these are different species cannot be substantiated. Until there is more information on this simple organism from Recent sediments, we prefer to place the 
specimens figured herein with $S$. sp. cf. S. confusa Brady.

Both McClellan (1966) and Kristan-Tollmann (1971b) record this species from the Silurian.

Family Saccamminidae Brady, 1884

Genus Amphitremoida Eisenack, 1938

Type species. Amphitremoida citroniforma, Eisenack, 1938 Amphitremoida sp. cf. A. citroniforma Eisenack, 1938

(Plate 1, figs 10 and 11)

1994 Ordovicina sp. Winchester-Seeto \& Bell: 205, figs 3.14, 3.15 .

Material. Four specimens from MUNG (sample 24.8), RUN (sample 70.6), GCR (sample 74.3) and Kuragh (sample 1).

Distribution. Garra Limestone, Wellington, NSW, pesavissulcatus conodont zones; Shogram Formation, Pakistan,? Late hermanni Conodont Zone.

Description. Test free; ovate chamber, widest at the centre and tapering evenly to the ends; test wall thin; surface shows grainy impressions; apertures rounded (?) about one-third width of test at the end of the chamber.

Dimensions. Maximum diameter, 134-316 $\mu \mathrm{m}$ (ave. $248 \mu \mathrm{m}$ ); minimum diameter, 68-200 $\mu \mathrm{m}$ (ave. $125 \mu \mathrm{m}$ ); $D_{\max } / D_{\min }, 1.6$ 1.9 .

Remarks. The species shows a variable number of grain impressions on the wall, but never any attached grains, and these impressions show a range in size. This species is not as elongate as A. eisenacki (Bell 1996, Conkin \& Conkin, 1964) or A. kielcensis Malec (1992: p. 280). Amphitremoida citroniforma has previously been recorded from the Ordovician (Llanvirnian) of northwest Germany (Riegraf \& Niemeyer, 1996) and from the lower Silurian of Illinois (Dunn, 1942); our species is only compared with $A$. citroniforma because of disjunct ranges.

Genus Lagenammina Rhumbler, 1911

Type species. Lagenammina laguncula Rhumbler, 1911 Lagenammina ovata Bell, 1996

(Plate 2, figs 1 and 2)

1996 Lagenammina ovata Bell: 92, fig. 7O, P.

Material. Two specimens from Kuragh 17.

Distribution. Taravale Formation, Victoria, perbonus-inversus conodont zones; Shogram Formation, Kuragh, Pakistan, ?Late falsiovalis Conodont Zone.

Dimensions. Diameter of test, $97 \mu \mathrm{m}$; Diameter of neck, $37 \mu \mathrm{m}$. Remarks. The specimens from Kuragh are about the same size as the intact tests recovered from southeastern Australia (Bell, 1996). The organic wall is finely reticulate, which agrees with the small, uniform grains used in the test of the normal agglutinated specimens.

Lagenammina $\mathrm{sp}$

(Plate 2, figs 3-5)

Material. Three broken specimens from MUNG (samples 8.4, 24.8) and GCR (sample 262).

Distribution. Garra Limestone, Wellington NSW, pesavis- sulcatus conodont zones.

Description. Test free; a flattened, rounded chamber (broken), followed by a short neck; aperture rounded at the end of a neck; wall of body chamber is coarsely reticulate, with larger and smaller defined areas, but the neck is relatively smooth.

Dimensions. Diameter of neck, $42-50 \mu \mathrm{m}$.

Remarks. Our specimens have broken body chambers, and it is not clear what the original shape would have been. Apart from size, Lagenammina sp. is close to L. talenti Bell 1996, but shows a more constricted neck. It is also similar to L. silnica Malec 1992 in having a short neck, but most of the body is missing in our specimens and so cannot be accurately compared. The difference between $L$. talenti and $L$. silnica may only reflect preservational differences.

Genus Saccammina Carpenter, 1869

Type species. Saccammina sphaerica Brady, 1871

Remarks. In addition to the main aperture, most of the species placed in Saccammina also have many small $(1-2 \mu \mathrm{m})$ pores scattered over the surface (e.g. Plate 2, fig. 6).

\section{Saccammina mea $\mathrm{n} . \mathrm{sp}$.}

(Plate 2, figs 6-9)

1994 Saccammina spp. Winchester-Seeto \& Bell: 202, figs 4.1, $4.2,4.4$

Derivation of name. From the Australian Aboriginal word mea, meaning open mesh, referring to the reticulate wall surface (Aboriginal language from Queensland).

Diagnosis. A species of Saccammina represented by an organic foraminiferal lining with a reticulated wall surface and aperture not raised.

Holotype. AMF 102656, Plate 2, fig. 8.

Material. Eleven specimens from MUNG (sample, 24.8, 76.2), RUN (samples 44.4, 70.6, 85.7) GCR (sample 106, 117.3, 412.2), MW (sample 24.6) and MSh (sample 1).

Type locality and horizon. RUN 44.4, $42.2 \mathrm{~m}$ above the base of the RUN section of the Garra Limestone, central NSW, Australia.

Description. Test free; globular; wall surface reticulate; a single large round aperture, flush with the test surface.

Distribution. Garra Limestone, Wellington, NSW, pesavissulcatus conodont zones; Martins Well Limestone, Broken River, Queensland., sulcatus Conodont Zone; Middle Shanda Beds, Siberia, serotinus Conodont Zone.

Dimensions. Diameter, 70-128 $\mu \mathrm{m}$ (Av. $95 \mu \mathrm{m}$ ); diameter of aperture, $5-9 \mu \mathrm{m}$ for nine specimens.

Remarks. Saccammina mea is distinguished from Saccammina sp. by its reticulate surface and from $S$. ampullacea (Crespin) and $S$. wingarri $\mathrm{n}$. sp. by the flush aperture.

Saccammina wingarri $\mathrm{n}$. sp.

(Plate 3, figs 1-3)

Derivation of name. From the local Australian Aboriginal word, wingarri, meaning neck, referring to the prominent neck (Gooniyandi language). 


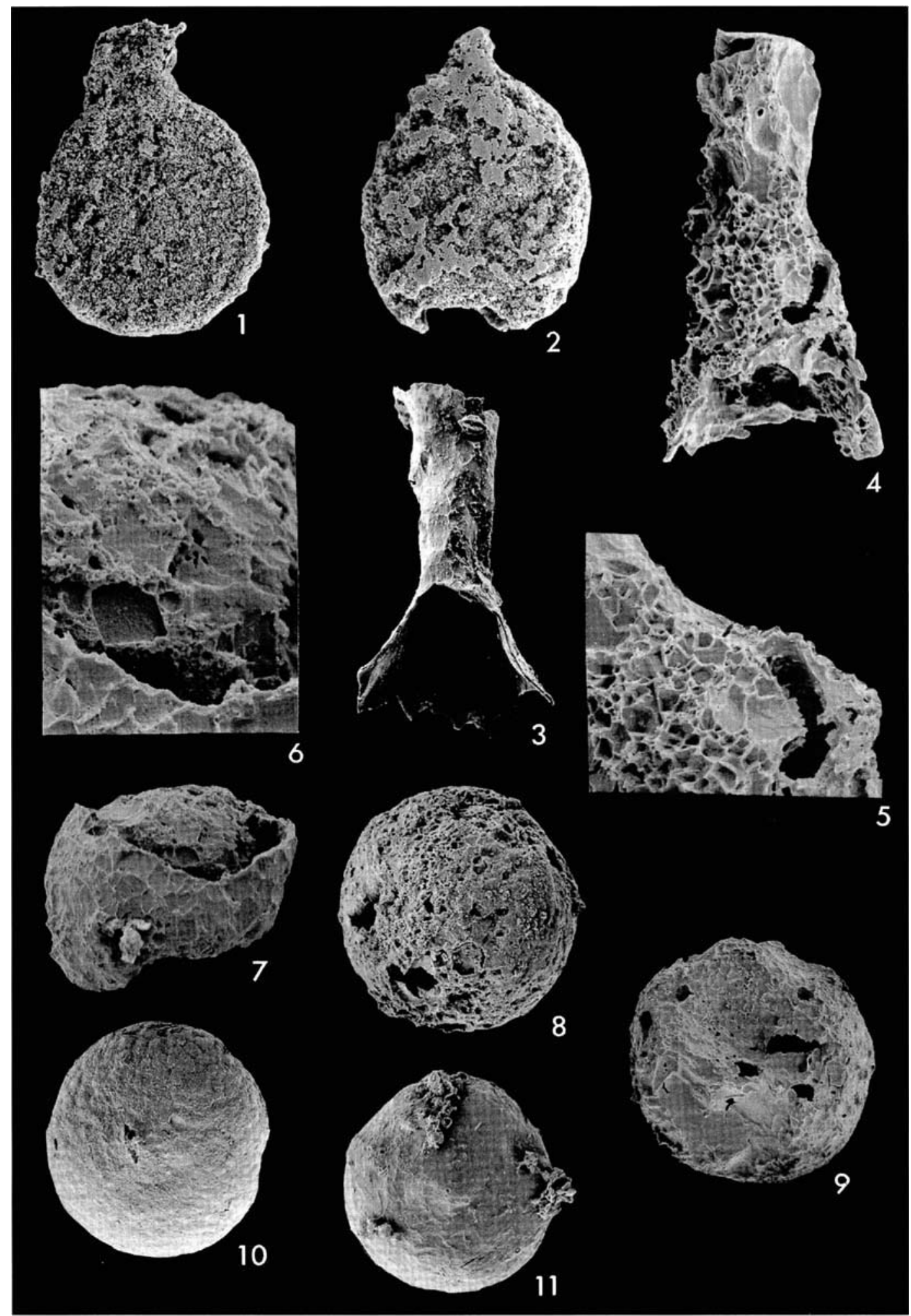

Explanation of Plate 2

figs 1, 2. Lagenammina ovata Bell, 1996: fig. 1, AMF102650, KG 17, $\times 350$; fig. 2, AMF102651, KG 17, $\times 450$. figs 3-5. Lagenammina sp.: fig. 3, AMF102652, GCR 262, $\times 500$; fig. 4, AMF102653, MUNG 24.8, $\times 350$; fig. 5, enlargement of fig. 4, $\times 700$. figs 6-9. Saccammina mea sp. nov.: fig. 6, enlargement of fig. 7, $\times 1500$; fig. 7, paratype, AMF102654, MUNG 24.8, $\times 400$; fig. 8, holotype, AMF102656, RUN 44.4, ×450; fig. 9, Paratype, AMF102655, GCR 106, ×400. figs 10, 11. Saccammina sp.: fig. 10, AMF102657, RUN 207, ×400; fig. 11, AMF102658, BOO 13.1, ×400. See text for abbreviations. 


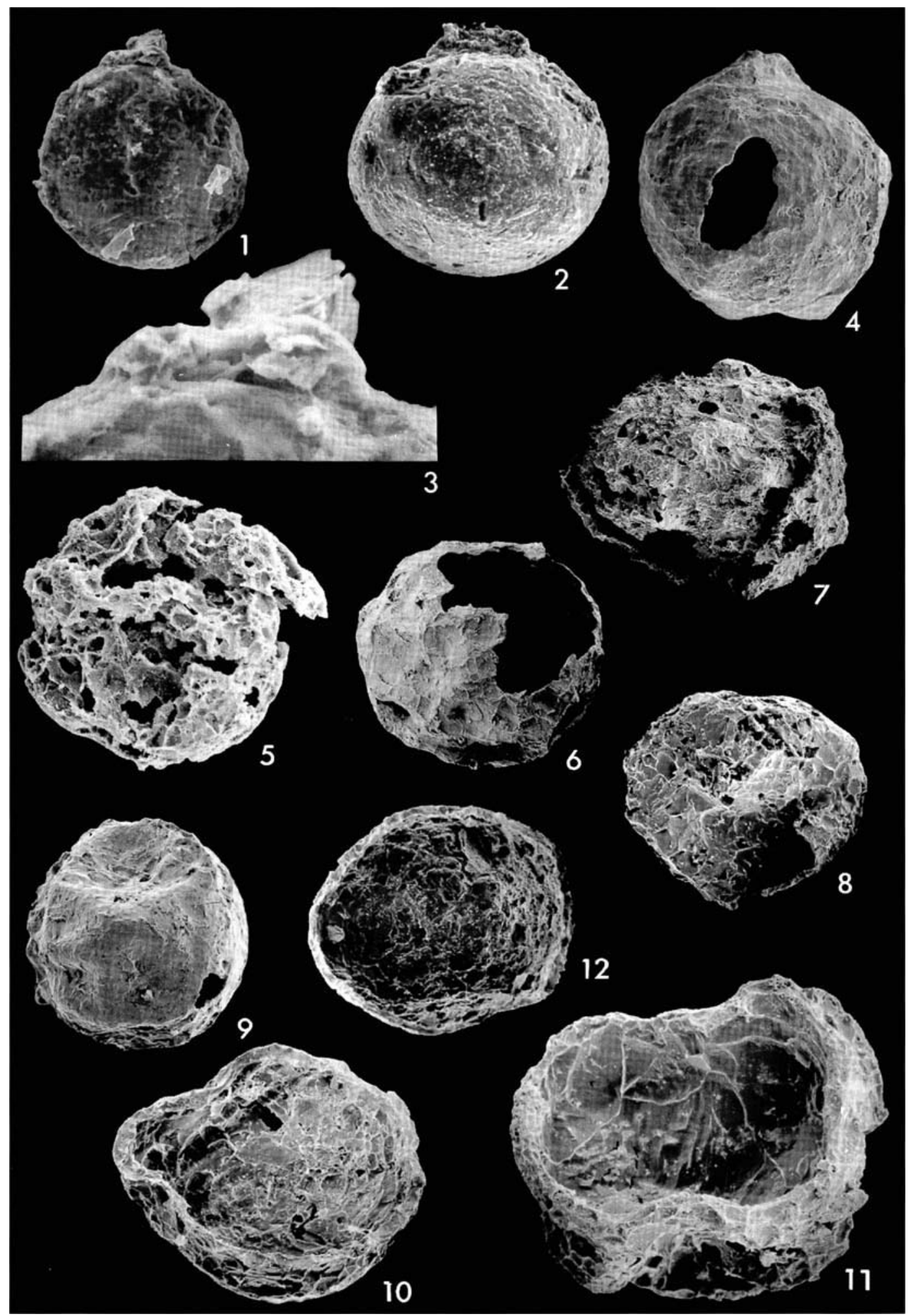

Explanation of Plate 3

figs 1-3. Saccammina wingarri sp. nov.: fig. 1, holotype, AMF102659, PD $166388.4, \times 400$; fig. 2, paratype, AMF102660, LSA $113, \times 400$; fig. 3 , enlargement of neck of holotype, $\times 1400$. fig. 4, Saccammina sp. cf. S. ampullacea (Crespin, 1961), AMF102661, MUNG 8.4, $\times 350$. fig. 5. Thurammina sp. cf. T. subsphaerica Moreman, 1930: AMF102662, MUNG 71.5, $\times 350$. figs 6, 7. Thurammina mirrka sp. nov.: fig. 6, paratype, AMF102663, GCR 401.8, ×300; fig. 7, holotype, AMF102664, GCR 412.2, ×400. fig. 8. Thurammina sp. cf. T. arcuata Moreman, 1930, AMF102665, GCR 37, ×350. fig. 9. Hemisphaerammina sp, AMF102666, GCR 117.3, $\times 350$. figs 10-12. Hemisphaerammina coolamon sp. nov.: fig. 10, paratype, AMF102667, MUNG 24.8, ×400; fig. 11, holotype, AMF102668, MUNG 6.3, ×400; fig. 12, paratype, AMF 102669, MUNG 24.8, $\times 350$. See text for abbreviations. 
Diagnosis. A species of Saccammina represented by an organic foraminiferal lining with a smooth wall surface and raised aperture.

Holotype. AMF102669, Plate 3, fig. 1

Material. Three specimens from PD $166 / 388.4 \mathrm{~m}$ and from LSA (sample 113).

Type locality and horizon. PD 166, $388.4 \mathrm{~m}$, Pillara Limestone, Pillara Range, Canning Basin, WA, Late Givetian-Early Frasnian, ?varcus Conodont Zone.

Description. Test free; globular; wall surface smooth; aperture rounded and raised on a short neck.

Distribution. Pillara Limestone, Pillara Range, Canning Basin, WA, disparilis-asymmetricus conodont zones; Serre Formation, Montagne Noire, France, asymmetricus Conodont Zone.

Dimensions. Diameter of chamber, $80-124 \mu \mathrm{m}$; diameter of neck, $23-40 \mu \mathrm{m}$; length of neck, $6-12 \mu \mathrm{m} ; D_{\text {neck }} / D_{\text {chamber }}, 0.3 ; L_{\text {neck }} /$ $D_{\text {chamber, }}, 0.1$.

Remarks. The very short, protruding neck (less than $10 \%$ of the test diameter) serves to separate this smooth walled species from Saccammina sp. S. wingarri differs from $S$. ampullacea in having a smooth wall surface and a smaller apertural neck. The neck appears to be of a different construction to the rest of the test wall and usually shows a blocky surface. The aperture is much larger than other Saccammina species. Although there are only a small number of specimens, this species is distinctive and readily distinguished from any other species of Saccammina; furthermore, specimens have been observed from Western Australia and from southern France, adding weight to the decision to erect a new species.

\section{Saccammina sp. cf. S. ampullacea (Crespin 1961)}

(Plate 3, fig. 4)

1994 Saccammina spp. Winchester-Seeto \& Bell: 202, figs 4.3, 4.5, 4.6.

Material. Three specimens from MUNG (sample 8.4) and GCR (samples 50.2, 412.2).

Distribution. Garra Limestone, Wellington, NSW, pesavissulcatus conodont zones.

Description. Test free; a globular chamber with a pronounced neck; wall surface reticulate; aperture rounded, on the end of a produced neck.

Dimensions. Diameter of chamber, 112-113 $\mu \mathrm{m}$; diameter of neck, $22-23 \mu \mathrm{m}$ for two specimens.

Remarks. Crespin (1961) placed her Late Devonian forms of this species in the genus Lagenammina because of the relatively long neck. Conkin \& Conkin (1968) found apparent attachment scars on either the body and/or neck and suggested placement in Oxinxis. Our specimens, although much smaller, show no evidence of an attachment scar and, as the neck is not excessively long, must be placed in Saccammina.

Saccammina sp.

(Plate 2, figs 10 and 11)

Material. Three specimens from RUN (sample 207), BOO (sample 13.1), Tyers Q. (sample 'Far end').

Distribution. Garra Limestone, Wellington, NSW, pesavis
Conodont Zone; Tyers Quarry, Cooper Creek Formation, Victoria, kindlei Conodont Zone; Boola Quarry, Coopers Creek Formation, Victoria, kindlei Conodont Zone.

Description. Test free; an organic foraminiferal lining; globular; wall surface smooth; a single round aperture flush with the surface.

Dimensions. Diameter, $78-90 \mu \mathrm{m}$; diameter of aperture, (approx.) 4-5 $\mu \mathrm{m}$.

Remarks. The flush aperture and the smooth wall surface serve to distinguish Saccammina sp., from any other known species. This is most probably a new species, but as there are only three specimens, it has been left in open nomenclature, pending the discovery of more individuals.

Genus Thurammina Brady, 1879

Type species. Thurammina papillata Brady, 1879

Thurammina mirrka $\mathrm{n}$. sp.

(Plate 3, figs 6 and 7)

Derivation of name. From the Australian Aboriginal word mirrka, meaning cave, referring to the Wellington Caves near the type locality (Ngiyampaa language).

Diagnosis. A species of Thurammina represented by an organic foraminiferal lining with rough wall and with aperture flush with surface.

Holotype. AMF102664, Plate 3, fig. 7.

Material. Four specimens from RUN (sample 237.6) and GCR (samples 106, 401.8, 412.2).

Type locality and horizon. GCR $412.2,410.1 \mathrm{~m}$ above the base of the GCR section of the Garra Limestone, central NSW, Australia.

Description. Test free; originally globular; moderate number of apertures (about 20 ), evenly distributed over test, and seemingly flush with surface, apertures vary in size; wall roughened.

Distribution. Garra Limestone, Wellington, NSW, pesavissulcatus conodont zones.

Dimensions. Diameter of chamber, $70-110 \mu \mathrm{m}$ (ave. $92 \mu \mathrm{m}$ for four specimens).

Remarks. Although the main feature of Thurammina are the apertures raised on papillae (Loeblich \& Tappan, 1988), we place this new species with Thurammina because of the large number of simple apertures, even though they appear not to be raised above the general wall surface; this may well represent a new genus, but we await further specimens from elsewhere in the world.

\section{Thurammina quadritubulata Dunn, 1942}

(Plate 4, fig. 1)

1942 Thurammina quadritubulata Dunn: 334, Plate 43, fig. 22 1961 Thurammina quadritubulata Dunn; Blumenstengel: p. 318

Material. One specimen from LSC (sample $1.6 \mathrm{~m}$ below 12b) Distribution. Serre Formation, Montagne Noire, France, ?linguiformis Conodont Zone.

Dimensions. Diameter, $=101 \mu \mathrm{m}$.

Remarks. Our specimen closely resembles Dunn's species from the Bainbridge Formation, Upper Silurian of Missouri. The only 
other Devonian record is by Blumenstengel (1961), who recorded $T$. quadritubulata from the Upper Devonian of Thuringa, Germany, but Conkin et al. (1968) suggest that this may be $T$. triradiata Gutschick \& Treckman; differences between these two species are minor (Conkin et al., 1968).

\section{Thurammina sp. cf. T. arcuata Moreman, 1930} (Plate 3, fig. 8)

Material. Five specimens from GCR (samples 37, 55, 285, 412.2).

Distribution. Garra Limestone, Wellington, NSW, pesavissulcatus conodont zones.

Description. Test free-globular (most specimens are distorted and compressed); a small number of simple apertures, flush with the surface of the test.

Dimensions. Diameter of chamber, 94-98 $\mu \mathrm{m}$; Diameter of aperture, $1-2 \mu \mathrm{m}$.

Remarks. Both smooth and reticulate surfaces occur on specimens in this species. Moreman's specimens had only four apertures, but Browne \& Schott (1963) extended the concept of the species to include specimens with more apertures and suggested that, with enough specimens, an ontogenetic sequence would show an array of apertural projections.

All previous records of $T$. arcuata are from the Silurian (Browne \& Schott, 1963, see reference list; Stewart \& Priddy, 1941; Dunn, 1942; McClellan, 1966).

Thurammina sp. cf. T. subsphaerica Moreman, 1930 (Plate 3, fig. 5)

1994 Thurammina sp. Winchester-Seeto \& Bell: 205, figs 4.1, 4.2, 4.3.

Material. Three specimens from MUNG (sample 71.5), GCR (sample 37) and MW (sample 31).

Distribution. Garra Limestone, Wellington, NSW, pesavissulcatus conodont zones; Martins Well Limestone, Broken River, Queensland, sulcatus Conodont Zone.

Description. Test free globular; numerous 'large', simple apertures raised on papillae; many smaller apertures between the papillae.

Dimensions. Diameter of chamber, $80-112 \mu \mathrm{m}$; diameter of 'large apertures' 3-10 $\mu \mathrm{m}$.

Remarks. Most of the specimens are broken, distorted and compressed, suggesting that the organic lining is very thin in this species. This species has been compared to $T$. subsphaerica because the papillae are rounded as in $T$. subsphaerica and there are simple apertures on each papilla, but the presence of small apertures between the papillae, ranging down to $0.5 \mu$, has not been observed before. Thurammina subsphaerica has been recorded from the Silurian of Illinois by Dunn (1942).

\section{Thurammina sp.}

(Plate 4, figs 2 and 3)

Material. One specimen from MW (sample 25.4).

Distribution. Martins Well Limestone, Broken River, Queensland, sulcatus Conodont Zone.
Description. Test free; an organic foraminiferal lining; 'blocky' surface, possibly due to distortion; few apertures of varying size, not raised from the surface.

Dimensions. Diameter of chamber, $69 \mu \mathrm{m}$; diameter of apertures, $0.5-1.5 \mu \mathrm{m}$.

Remarks. As this is the only specimen showing this surface, it is unclear as to whether it is not purely a preservational feature, (e.g. the impressions of pyrite framboids).

Family Hemisphaeramminidae Loeblich \& Tappan, 1957 Genus Hemisphaerammina Loeblich \& Tappan, 1957

Type species. Hemisphaerammina batalleri Loeblich \& Tappan, 1957

Hemisphaerammina coolamon $\mathrm{n} . \mathrm{sp}$. (Plate 3, figs 10-12)

1994 Hemisphaerammina sp. Winchester-Seeto \& Bell: 205, fig. 4.7.

Derivation of name. From the Australian Aboriginal word coolamon, meaning water carrier, referring to a water vessel of the same shape (Aboriginal language from Queensland).

Diagnosis. A species of Hemisphaerammina represented by an organic foraminiferal lining with a reticulated wall surface.

Holotype. AMF102668, Plate 3, fig. 11

Material. Five specimens from MUNG (samples 6.3, 24.8) and MW (sample 49).

Type locality and horizon. MUNG 6.3, $6.2 \mathrm{~m}$ above the base of the MUNG section of the Garra Limestone, central NSW, Australia.

Distribution. Garra Limestone, Wellington, NSW, pesavissulcatus conodont zones; Martins Well Limestone, Broken River, Queensland, sulcatus Conodont Zone.

Description. Test apparently formerly attached; hemispherical chamber with a basal membrane; a thick flat attachment surface; wall surface reticulate; no apparent aperture.

Dimensions. Diameter of chamber, $83-116 \mu \mathrm{m}$ (Av. $90.5 \mu \mathrm{m}$ for five specimens).

Remarks. The basal attachment surface may show a partial lip or flange surrounding the test; this flange was a diagnostic feature used in the separation of Metamorphina (Browne \& Schott, 1963) from Hemisphaerammina, but Loeblich \& Tappan (1988) have synonymized these two genera. A number of our specimens only show a partial basal membrane.

\section{Hemisphaerammina sp.}

(Plate 3, fig. 9)

1994 Hemisphaerammina sp. Winchester-Seeto \& Bell: 205, fig. 4.6.

Material. Two specimens from MUNG (sample 8.4) and GCR (sample 117.3).

Distribution. Garra Limestone, Wellington, NSW, pesavissulcatus conodont zones.

Description. Test an organic foraminiferal lining; apparently initially attached; hemispherical chamber with a smooth, firmly attached basal membrane; wall thick, smooth; no basal flange. 
Dimensions. Diameter of chamber, $86-138 \mu \mathrm{m}$.

Remarks. Hemisphaerammina sp. differs from Hemisphaerammina coolamon $\mathrm{n}$. $\mathrm{sp}$. in the smooth wall and absence of a basal flange. It is similat to the Recent $H$. bradyi Loeblich \& Tappan, but is not as domed and has a thicker wall.

This is probably a new species, but has been left in open nomenclature, pending the discovery of more individuals.

Genus Webbinelloidea Stewart \& Lampe, 1947

Type species. Webbinelloidea similis Stewart \& Lampe, 1947 Webbinelloidea similis Stewart \& Lampe, 1947

(Plate 4 fig. 13)

1947 Webbinelloidea similis Stewart \& Lampe: 535, pl. 78, fig. 8.

1970 Webbinelloidea similis Stewart \& Lampe; Conkin \& Conkin: 4-14, pl. 1, figs 1-31; pl. 2, figs 1-27; pl. 3, figs $1-16$; pl. 4, figs $1-35$.

1984 Webbinelloidea similis Stewart \& Lampe; Malec: 560 561 , pl. 1, figs 1-20; pl. 2 figs $1-12$.

1985 ?Webbinelloidea sp. Stewart \& Lampe; Gnoli \& Serpagli: 214, pl. 1, fig. 21.

1988 Webbinelloidea similis Stewart \& Lampe; Malec \& Studencki: 8485 , pl. 1, figs 13, 15-18; pl. 2, figs 1-4; pl. 3, figs $1-5$.

1992 Webbinelloidea similis Stewart \& Lampe; Malec: 282, pl. 1, fig. 6; pl. 2, figs 6,10 ; pl. 3, figs 6 , 9; pl. 4, figs $1-9$.

1994 Hemisphaerammina sp. Winchester-Seeto \& Bell: 205, fig. 4.8 .

For further synonyms see, Conkin \& Conkin (1970).

Material. One specimen, from RUN (sample 199.3).

Distribution. Garra Limestone, Wellington, NSW, pesavis Conodont Zone; Góry Świetokrzyskie Mountains, Poland, Upper Emsian-Lower Eifelian; Columbus Formation, USA, patulus-costatus conodont zones; Delaware Formation, USA, kocklianus Conodont Zone; Corti Baccas third section, Sardinia, Lower Lochkovian.

Description. Test probably originally attached; domed, but flattened; wall surface smooth; no apparent basal membrane; aperture a small everted opening at top of dome.

Dimensions. Diameter of both chambers, $141 \mu \mathrm{m}$.

Remarks. The small domal aperture separates Webbinelliodea from Hemisphaerammina (Conkin \& Conkin, 1970). These workers showed that, contrary to the initial description of $W$. similis (Stewart \& Lampe, 1947), there is a small aperture present which could be described as '. . a single subcentrally located aperture which resembles a pin prick and looks as if a pin had been forced from the exterior into the interior of the test. An apertural protuberance is present on the interior of the shell.' In our case the internal edge of the aperture is fairly recurved; in normal sized agglutinated test foraminiferans from this locality the external appearance of the aperture is a very small arcuate opening. $W$. similis ranges from the Middle Devonian to Lower Carboniferous in the USA (Conkin \& Conkin, 1981, with synonymy), and in Poland occurs in the Lower-Middle Devonian (Malec, 1992).

Genus Hyperammina Brady, 1878
Type species. Hyperammina elongata Brady, 1878

Hyperammina devoniana Crespin, 1961

(Plate 4, figs 11 and 12)

1961 Hyperammina devoniana Crespin: 1961; 406, pl. 64, figs $1-6$.

1994 Hyperammina spp. Winchester-Seeto \& Bell: 202, figs 2.1, 2.2 .

Material. Four specimens from MUNG (sample 24.8), GCR (sample 38) and MW (sample 39.9).

Distribution. Garra Limestone, Wellington, NSW, pesavissulcatus conodont zones; Martins Well Limestone, Broken River, Queensland, sulcatus Conodont Zone; Virgin Hills Formation, Canning Basin, ?falsiovalis Conodont Zone.

Dimensions. Length, 216-371 $\mathrm{m}$; (Av. $294 \mu \mathrm{m}$ ); diameter of proloculum, 71-90 $\mu \mathrm{m}$ (Av. $81 \mu \mathrm{m}$ ); diameter minimum, 50$79 \mu \mathrm{m}$ (Av. $61 \mu \mathrm{m})$.

Remarks. Conkin \& Conkin (1968) place this species in Tolypammina as they believe that Crespin's specimens show attachment scars which are not found in Hyperammina; however, we do not agree with Conkin \& Conkin and prefer to leave it in Hyperammina. Although our specimens are much smaller than Crespin's (i.e. 250-300 $\mu \mathrm{m}$ compared with $820 \mu \mathrm{m}$ ), the relative length of the tubular section versus the diameter of the proloculum remains the same (about $5: 1$ ).

Hyperammina sp. cf. H. sappingtonensis Gutschick, 1962 (Plate 4, figs 4-8)

1994 Hyperammina spp. Winchester-Seeto \& Bell: 202, figs 2.3, $2.4,2.5$ ?

Material. Two microspheric forms from Pt. Hibbs (sample 68669) and MSh (sample 2); 18 megalospheric specimens from RUN (sample 70.6); GCR (samples 38, 53.7); MW (samples 34, 39.9); KE DDH1 (depths 448.51, 511, 805.25, $1026.54 \mathrm{~m}$ ), MSh (samples 1, 2).

Distribution. Microspheric form: Pt Hibbs Limestone, Tasmania, kindlei Conodont Zone; Middle Shanda Beds, Siberia, serotinus Conodont Zone; megalospheric form: Garra Limestone, Wellington, NSW, pesavis-sulcatus conodont zones; Martins Well Limestone, Broken River, Queensland, sulcatus Conodont Zone; Amphitheatre Group, Darling Basin, NSW, pesavis-sulcatus conodont zones; Middle Shanda Beds, Siberia, serotinus Conodont Zone.

Dimensions. Microspheric forms: Length, 117-173 $\mu \mathrm{m}$; diameter of proloculum, 33-53 $\mu \mathrm{m}$. Megalospheric forms: length, 186$400 \mu \mathrm{m}$ (ave. $219.5 \mu \mathrm{m}$ ); diameter of proloculum, 35 $104 \mu \mathrm{m}$ (ave $57 \mu \mathrm{m}$ ).

Remarks. This species is characterized by a globular proloculum with a marked constriction between the prolocular chamber and the second chamber. This linear chamber may either taper towards the apertural end (Plate 4, fig. 8) or become flaring (Plate 4, fig. 5) and even shows the characteristic 'hourglass' constriction of Hyperammina (Plate 4, fig. 6). Conkin \& Conkin (1964) determined that $H$. sappingtonensis existed as both microand megalospheric forms. Specimens observed in this study have prolocular sizes which fit fairly easily into the size ranges given 


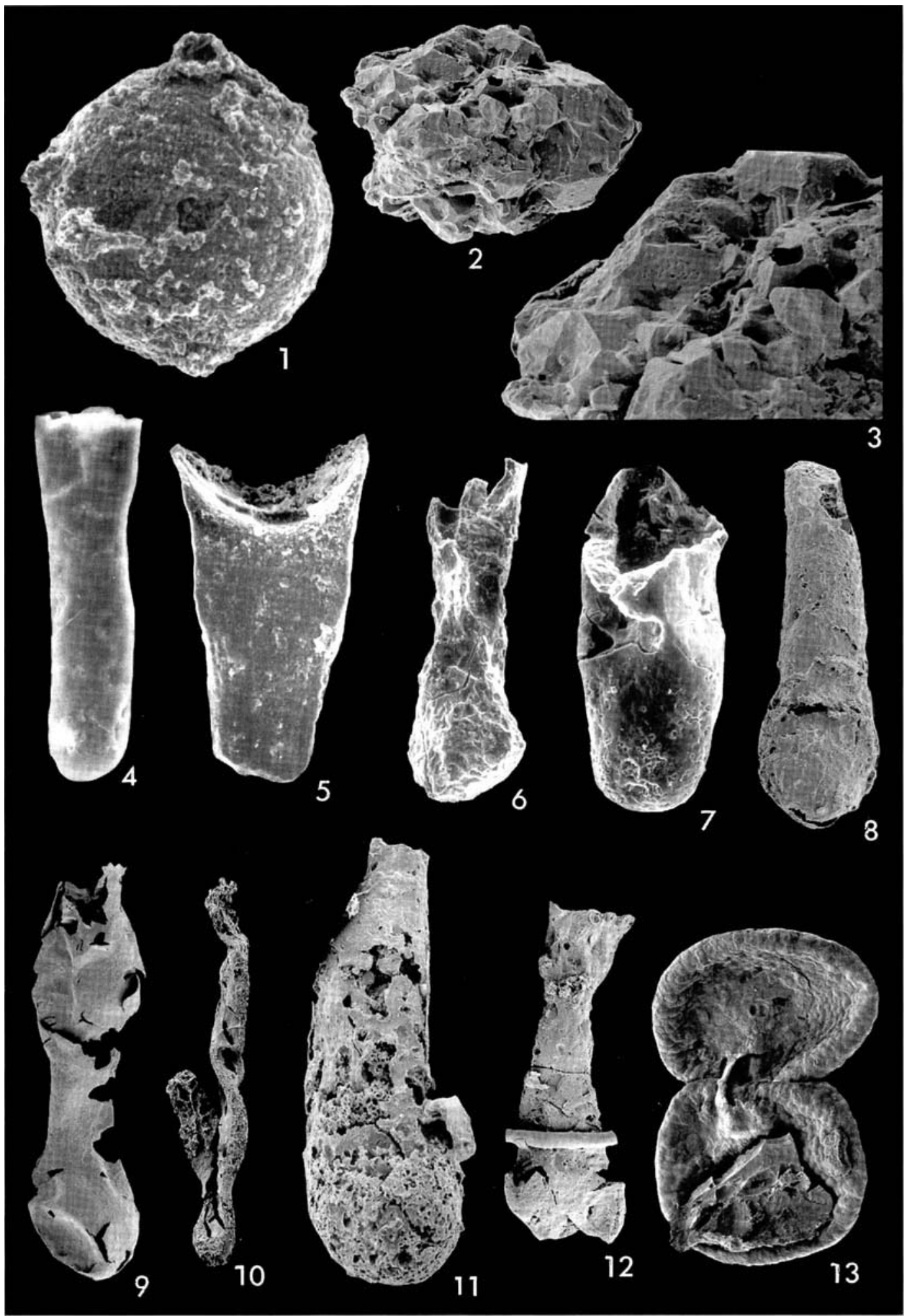

Explanation of Plate 4

fig. 1. Thurammina quadritubulata Dunn, 1942, AMF102670, LSC $1.6 \mathrm{~m}$ below 12b, $\times 400$. figs 2, 3. Thurammina sp.: fig. 2, AMF102671, MW 13.7, $\times 400$; fig. 3, enlargement of fig. 2, $\times 900$. figs 4-8. Hyperammina sp. cf. H. sappingtonensis Gutschick, 1962: fig. 4, AMF102674, KE DDH1 448.51, $\times 300$; fig. 5, AMF102672, MSh 2, $\times 400$; fig. 6, AMF102675, MSh 2, $\times 400$; fig. 7, AMF102673, Pt. Hibbs 68669, $\times 400$; fig. 8, AMF102676, MW 39.9, (×300). fig. 9, Reophanus proavitus sp. nov., holotype, AMF102677, GCR 105, $\times 200$. fig. 10. Tolypammina tantala Bell, 1996, AMF102678, GCR 53.7, $\times 120$. Figs 11, 12. Hyperammina devoniana Crespin, 1961: fig. 11, AMF102679, MW 39.9, $\times 300$; fig. 12, AMF102680, GCR 38, $\times 200$. fig. 13. Webbinelloidea sp. cf. W. similis Stewart \& Lampe, 1947, AMF102681, RUN 199.3, $\times 300$. See text for abbreviations. 
for this species. In the megalospheric forms the ratio of prolocular diameter to length of specimen is one to three or four, whereas in the microspheric form this ratio is one to seven or eight. The microspheric form shows a gradual increase in test diameter from the proloculum, whereas in the megalospheric form the proloculum is slightly constricted from the tubular chamber, which gradually increases in diameter towards the apertural end. Our major difference to $H$. sappingtonensis is that the microspheric form is very much shorter than the megalospheric form.

$H$. sappingtonensis is recorded from the Upper Devonian of Louisiana (Conkin \& Conkin, 1964) and the Lower Carboniferous (Kinderhookian) of Missouri and Illinois (Conkin et al., 1968). Conkin \& Conkin (1964) have suggested that $H$. sappingtonensis is almost certainly a junior synonym of $H$. kahlleitensis Blumenstegal 1969 from the Upper Devonian of Germany, but that doubt exists as to the size range given for the German specimens.

Family Ammodiscidae Reuss, 1962

Genus Tolypammina Rhumbler, 1895

Type species. Hyperammina vagans Brady, 1879

Tolypammina tantula Bell, 1996

(Plate 4, fig. 10)

1994 Hyperammina spp. Winchester-Seeto \& Bell: 206, figs $3.12,3.13$.

1996 Tolypammina tantula Bell: 99, figs 10C-E.

Material. Two specimens from RUN (sample 44.5) and GCR (sample 53.7).

Distribution. Garra Limestone, Wellington, NSW, pesavis sulcatus conodont zones; Bonanza Gully, Buchan Caves Limestone, Victoria, perbonus Conodont Zone.

Description. Test probably formerly attached; a small proloculus followed by an undivided tubular chamber; aperture at the end of a second chamber, round; wall smooth.

Dimensions. Length, $440-500 \mu \mathrm{m}$, diameter of proloculum, $42-$ $50 \mu \mathrm{m}$.

Remarks. Our specimens have an attached basal floor and, apart from size differences, appear to be identical to $T$. tantala from Buchan.

Family Telamminidae Loeblich \& Tappan, 1985

Genus Reophanus Saidova, 1970

Type species. Hormosina ovicula Brady, 1879

Reophanus proavitus $\mathbf{n} . \mathbf{s p}$.

(Plate 4, fig. 9)

1994 Reophax sp. Winchester-Seeto and Bell: 206, figs 3.7, 3.8.

Derivation of name. From the Latin word proavitus, meaning ancestor.

Diagnosis. A species of Reophanus represented by an organic foraminiferal lining with smooth surface.

Holotype. AMF102677, Plate 4, fig. 9.

Material. Three specimens from RUN (sample 85.7) and GCR (samples 105, 290.9).
Type locality and horizon. GCR 105, $105 \mathrm{~m}$ above the base of the GCR section of the Garra Limestone, Wellington, central NSW, Australia.

Distribution. Garra Limestone, Wellington, NSW, pesavissulcatus conodont zones,

Dimensions. Length, 135-335 $\mu \mathrm{m}$; diameter of proloculum, 40 $88 \mu \mathrm{m}$; diameter of final chamber, $43-88 \mu \mathrm{m}$.

Description. Test free; a linear arrangement of chambers; initially a pyriform proloculum followed by a second pyriform chamber of similar size; surface smooth; aperture rounded, at the end of the neck.

Remarks. The pyriform chambers and the short interconnecting neck indicate that this species is referable to the genus Reophanus and not Reophax as emended by Brönnimann \& Whittaker (1980). Although only specimens with two chambers are known, in each case the neck is broken, so multithalamous specimens may be possible. Because of the time differences (Reophanus is only recorded from the Recent; Loeblich \& Tappan, 1988) and the much smaller size than the Recent species ( $R$. oviculus), a new name is proposed.

Loeblich \& Tappan (1988) state that Reophanus does not have an inner organic lining, but Mendelson (1982) observed the presence of a lining in his Recent specimens of $R$. oviculus (Brady).

Gen. et sp. indet.

(Plate 1, figs 12 and 13)

Material. Three specimens from Gel. Rd. (sample 16T/65).

Distribution. Taravale Formation, eastern Victoria, serotinus Conodont Zone.

Description. Test free; an organic foraminiferal lining; globular; no apparent large aperture, but the otherwise smooth wall is perforated with many small pores, rounded to angular, placed randomly over the surface.

Dimensions. Diameter, $67-73 \mu \mathrm{m}$; diameter of apertures, $0.5 \mu \mathrm{m}$. Remarks. Although these specimens may belong in Psammosphaera, the many perforations have not been seen in any other member of that genus. A number of the larger perforations seem to have a slightly raised smooth ridge about them. It is, of course, possible that these perforations are the result of chemical reactions during processing.

\section{SUMMARY}

The present study of Devonian (Lochkovian to Frasnian) organic foraminiferal linings recognizes 24 species, of which six are new. Organic foraminiferal linings show potential for inter- and intra-continental biostratigraphic correlations as some species have a wide geographical, but stratigraphically limited, range.

This study is the first to integrate taxonomic and biostratigraphic information from foraminiferal linings with that of intact agglutinate foraminiferans from Palaeozoic sequences. This recognition of the significance of the linings opens up a new source of foraminiferal fossils from which to draw information. Thus we now have the potential to not only examine the full size range of foraminiferans and to gain a more complete understanding of the range of variation within these organisms, but also to appreciate the influence of environmental factors on their 
physiology and distribution.

\section{ACKNOWLEDGEMENTS}

We thank Professor John Talent and Associate Professor Ruth Mawson for their continuing interest and support in our studies. We greatly appreciate the meticulous work by David Mathieson (printing) and Alison Basden (plate preparation) in ensuring the quality of the plates. We also thank the New South Wales Geological Survey for access to core samples from the Darling Basin. This paper is a contribution to the International Geological Correlation Program, Project 421, entitled: North Gondwanan Mid-Palaeozoic Bioevent/Biogeography Patterns in Relation to Crustal Dynamics.

\section{Manuscript received November 1997 Manuscript accepted February 1999}

\section{REFERENCES}

Allen, K., Roberts, S. \& Murray, J. W. 1998. Fractal grain distribution in agglutinate foraminifera. Paleobiology, 24: 349-358.

Bell, K. N. 1996. Early Devonian (Emsian) agglutinated foraminiferans from Buchan and Bindi, Victoria, Australia. Proceedings of the Royal Society of Victoria, 108: 73-106.

Bembrick, C. 1997. The Darling Basin Devonian sequence. A re-appraisal Preliminary Report. NSW Geological Survey, Unpublished Report GS1997/214, June, 1997: 1-51.

Bender, H. 1995. Test structure and classification in agglutinated Foraminifera. In: Kaminski, M. A., Geroch, S. \& Gasinski, M. A. (Eds), Fourth International Workshop on Agglutinated Foraminifera. Grzybowski Foundation Special Publications, 3: 27-70.

Blumenstegal, H. 1961. Foraminiferen aus dem Thrüinger Oberdevon. Geologie, 10: 316-335.

Brady, H. B. 1871. On Saccammina carteri, a new foraminifer from the Carboniferous limestone of Northumberland. Annals and Magazine of Natural History, Series 4, 7: 177-184.

Brady, H. B. 1878. Notes on some of the reticularian and radiolarian Rhizapoda (Foraminifera and Polycystina) of the North Polar Expedition of 1875-1876. Annals and Magazine of Natural History, Series 5, 1: 425-440.

Brady, H. B. 1879. Notes on some of the Reticularina Rhizopoda of the Challenger Expedition. 1. On new or little known arenaceous types. Quarterly Journal of Microscopical Science, 19: 20-63.

Brady, H. B. 1881. Notes on some of the reticularian Rhizopoda of the Challenger Expedition, Part 2. Further notes on new species. Quarterly Journal of the Microscopical Society, 21: 31-71.

Brady, H. B. 1884. Report on the foraminifera dredged by H.M.S 'Challenger' during the years 1873-1876. Report of the Scientific Results, Zoology 9: 1-814.

Brönnimann, P. \& Whittaker, J. E. 1980. A revision of Reophax and its type species, with remarks on several other Recent hormosinid species (Protozoa: Foraminiferida) in the collections of the British Museum (Natural History). British Museum, Natural History, Bulletin (Zoology), 39: 259-272

Browne R. G. \& Schott, V. J. 1963. Arenaceous Foraminifera from the Osgood Formation at Osgood, Indiana. Bulletin of American Paleontology, 49: 191-242.

Burnett, B. R. 1979. Quantitative sampling of microbiota of the deepsea benthos. 2 Evaluation of technique and introduction to the biota of the San Diego Trough. Transactions of the American Microscopical Society, 98: 233-242.

Carey S. P. \& Berry, R. F. 1988. Thrust sheets at Point Hibbs, Tasmania: palaeontology, sedimentology and structure. Australian Journal of Earth Sciences, 35: 169-179.

Carpenter, W. B. 1869. On the rhizopidal fauna of the deep sea. Proceedings of the Royal Society of London, 18: 59-62.

Colbath, G. K. 1990. Devonian (Givetain-Frasnian) organic-walled phytoplankton from the Limestone Billy Hills reef complex, Canning Basin, Western Australia. Palaeontolographica, Abteilung B, 217: 87-
145.

Conkin, J. E. \& Conkin, B. M. 1964. Devonian Foraminifera: Part 1, the Louisiana limestone of Missouri and Illinois. Bulletins of American Paleontology, 47: 53-105.

Conkin, J. E. \& Conkin, B. M. 1968. A revision of some Upper Devonian foraminifera from Western Australia. Palaeontology, 11: 601-609.

Conkin J. E. \& Conkin, B. M. 1970. Middle Devonian arenaceous Foraminifera of central Ohio. Part 1-Revision of the genus Webbinelloidea Stewart \& Lampe, 1947. Micropaleontology, 16: 1-14.

Conkin, J. E. \& Conkin, B. M. 1981. Early Mississippian (Kinderhookian) smaller foraminifera from the McCraney Limestone of Missouri and Illinois. University of Louisville Studies in Paleontology and Stratigraphy, 15: 1-40.

Conkin, J. E., Conkin, B. M. \& Canis, W. F. 1968. Mississippian foraminifera of the United States. Part 3-The limestones of the Chouteau Group in Missouri and Illinois. Micropaleontology, 14: 133178

Conkin, J. E., Conkin, B. M. \& Thurman, E. D. 1979. Inauris and Sorosphaerella, new genera of Paleozoic agglutinate foraminifera, and their stratigraphic significance. University of Louisville Studies in Paleontology and Stratigraphy, 10: 1-11.

Crespin, I. 1961. Upper Devonian Foraminifera from Western Australia. Palaeontology, 3: 397-409.

Delage, Y. \& Hérouard, E. 1896. Traité de zoologie concrète. Tome 1. La cellule et les protozoaires. Paris, $584 \mathrm{pp}$.

Dunn, P. H. 1942. Silurian Foraminifera of the Mississippi Basin Journal of Paleontology, 16: 317-342.

Eichwald, C. E. von 1830. Zoologia Specialis. Vol. 2. Eichwaldus, Vilnae, $323 \mathrm{pp}$

Eisenack, A. 1932. Neue mikrofossilien des baltischen Silurs. 2. Paläontologische Zeitschrift, 14: 257-277.

Eisenack, A. 1938. Neue mikrofossilien des baltischen Silurs. Paläontologische Zeitschrift, 19: 223-243.

Gnoli, M. \& Serpagli, E. 1985. An unusually preserved foraminiferal association from the Upper Silurian-Lower Devonian beds of southwest Sardinia. Bolettino della Sociatá Paleontologica Italiana, 23: 211 220.

Gooday, A. J. 1986a. Soft-shelled foraminifera in meiofaunal samples from the bathyal Northeast Atlantic. Sarsia, 71: 278-287.

Gooday, A. J. 1986b. Meiofaunal foraminiferans from the bathyal Porcupine Seabight (north-east Atlantic): size structure, standing stock, taxonomic composition, species diversity and vertical distribution in the sediment. Deep Sea Research, 33: 1345-1373.

Gutschick, R. C. 1962. Arenaceous foraminifera from oncolites in the Mississippian Sappington formation of Montana. Journal of Paleon tology, 36: 1291-1304.

Gutschick, R. C. 1986. Middle Ordovician Foraminifera including Reophax from the Mifflin Formation, Platteville Group of Illinois. Journal of Paleontology, 60: 233-248.

Haeckel, E. 1894. Systematische Phylogenie. Theil 1, Systematische Phylogenie der Protisten and Pfanzen. Reimer, Berlin, $400 \mathrm{pp}$.

Hedley, R. H. 1962. The significance of an 'inner chitinous lining' in Saccamminid organization, with special reference to a new species of Saccammina (Foraminifera) from New Zealand. New Zealand Journal of Science, 5: 375-389.

Heron-Allen, E., 1915. A short statement upon the theory, and phenomena of purpose and intelligence exhibited by the protozoa, as illustrated by selection and behaviour in the foraminifera. Journal of Microscopy, 6: 547-557.

Hohenneger, J. 1990. On the way to the optimal suprageneric classification of agglutinating foraminifera. In Hemleben, C., Kaminski, M. A. Kuhnt, W. \& Scott, B. D. (eds) Paleoecology, Biostratigraphy. Paleoceanography and Taxonomy of Agglutinated Foraminifera. Dordrecht, Kluwer, 77-104.

Holbourn, A. E. L. \& Kaminski, M. A. 1995. Saccammina crespinae, nom. nov., a new name for Psammosphaera parva, Crespin, 1963. In Kaminski, M. A., Geroch, S. \& Gasínski, M. A. (eds) Proceedings of the Fourth International Workshop on Agglutinated Foraminifera Krakow, Poland, September 12-19, 1993. Grzybowski Foundation Special Publication, 3: 158.

Klapper, G. 1988. The Montagne Noire Frasnian (Upper Devonian) 
conodont Succession. Canadian Society of Petroleum Geologists, Memoirs, 14: 449-468.

Klapper, G. \& Feist, R. 1985. Stratigraphy and conodonts in pelagic sequences across the Middle-Upper Devonian boundary, Montagne Noire, France. Palaeontographica Abteilung A, 188: 1-18.

Kristan-Tollmann, E. 1971a. Revision der altpaläozoischen Sorosphaeren (Foram.) Neues Jahrbuch für Geologie und Paläontologie, Monatshefte, 1971: 171-180.

Kristan-Tollmann, E. 1971b. Sandschalige Foraminiferen aus dem Silur der Nördlichen und Südlichen Grauwackenzone Österriechs. Neues Jahrbuch für Geologie und Paläontologie, Abhandlungen, 137: 249-283.

Loeblich, A. R. \& Tappan, H. 1961. Eleven new genera of Foraminifera. U.S. National Museum Bulletin, 215: 223-232.

Loeblich, A. R. \& Tappan, H. 1985. Some new and redefined genera and families of agglutinated Foraminifera 1. Journal of Foraminiferal Research, 15: 91-104.

Loeblich, A. R. \& Tappan, H. 1988. Foraminiferal Genera and their Classification. Van Nostrand Reinhold, New York, 2 Vols, 1-2047.

McClellan, W. A. 1966. Arenaceous foraminifera from the Waldron Shale (Niagaran) of S-E Indiana. Bulletins of American Paleontology, 50: $244-518$.

Mabillard, J. E. \& Aldridge, R. J. 1982. Arenaceous foraminifera from the Llandovery/Wenlock boundary beds of the Wenlock Edge area, Shropshire. Journal of Micropalaeontology, 1: 129-136.

Malec, J. 1984. Webbinelloidea similis Stewart \& Lampe (Foraminiferida) from Eifelian of $\not$ agów syncline. Kwartalnik Geologiczny, 28: 555-568 (in Polish, English summary).

Malec, J. 1992. Arenaceous foraminifera from Lower-Middle Devonian boundary beds of western part of the Góry Świẹtokrzyskie Mountains. Annales Societatis Geologrum Poloniae, 62: 269-287.

Malec, J. \& Studencki, M. 1988. Lower Eifelian at Szydlówek in Kielce. Biuletyn Instytut Geologiczny, (Warsaw), 358: 73-92 (in Polish, English summary).

Mawson, R. 1987. Early Devonian conodont faunas from Buchan and Bindi, Victoria, Australia. Palaeontology, 30: 251-297.

Mawson, R. \& Talent, J. A. 1994. Age of Early Devonian carbonate fan and isolated limestone clasts and megaclasts, east-central Victoria. Proceedings of the Royal Society of Victoria, 106: 31-70.

Mawson, R., Talent, J. A. \& 12 others 1988. Conodont data in relation to resolution of stage and zonal boundaries for the Devonian of Australia. Memoir of the Canadian Society of Petroleum Geologists, 14: 485-527.

Mendelson, C. V. 1982. Surface texture and wall structure of some Recent species of agglutinated Foraminifera (Textulariina). Journal of Paleontology, 56: 295-307.

Molloy, P. 1979. Conodont faunas from north-west Pakistan. Unpublished MSc Thesis, Macquarie University, Sydney.

Moreman, W. L. 1930. Arenaceous foraminifera from the Ordovician and Silurian of Oklahoma. Journal of Paleontology, 4: 42-59.

Mound, M. C. 1968. Arenaceous Foraminiferida and zonation of the Silurian rocks of northern Indiana. Geological Survey of Indiana, Bulletin, 38: 126 pp.

Paris, F. 1981. Les Chitinozoaires dans le Paleozoïqué de Sud-ouest de l'Europe. Mémoires de la Société géologique et minéralogique de Bretagne, 26: 1-412.

Pawlowski, J. 1991. Distribution and taxonomy of some benthic tiny foraminifers from the Bermuda Rise. Micropaleontology, 37: 163-172.

Petelin, V. P. 1970. Composition of agglutinate material in the shells of certain modern foraminifera. Oceanology, 10: 46-53.

Philip, G. M. \& Pedder, A. E. H. 1968. The correlation of some Devonian limestones of New South Wales and Victoria. Geological Magazine, 104: 232-239.

Rehfisch, M. W. \& Webb, J. A. 1993. The Early Devonian Coopers Creek Limesone, a re-deposited deep-water limestone within the Melbourne Trough, southeastern Australia. Australian Journal of Earth Sciences, 40: 575-589.

Reuss, A. E. 1962. Entwurf einer systematischen Zusammenstellung der Foraminiferen. Akademie der Wissenschaften zu Wien, mathematischenaturwissenschaftliche Classe, 44: 355-396.

Rhumbler, L. 1895. Entwurf eines natürlichen Systems der Thalamor- phoren. Gesellschaft der Wissenschaften zu Gottingen, mathematischephysikalische Klasse, Abhandlungen, 1: 51-98.

Rhumbler, L. 1911. Die Foraminiferan (Thalamophoren) der PlanktonExpedition. Ergebnisse der Plankton-Expedition der Humboldt-Stiftung, Kiel and Leipzig, 3: 1-331.

Riegraf, W. \& Niemeyer, J. 1996. Agglutinierte Foraminiferen aus Graptolithen-Schwarzschiefean des Llanvirnium (Ordovizium) von Plettenberg im Sauerland (Nordrhein-Westfalen, NW Deutschland). Paläontologische Zeitschrift, 70: 19-30.

Saidova, Kh. M. 1970. [Benthic foraminifera in the Kurile-Kamchatka region based on data of the $39^{\text {th }}$ cruise of the R/V 'Vityaz']. Trudy Instituta Okeanologii, 86: 134-161 [in Russian].

Schulze, F. E. 1875. Zoologische Ergenisse der Nord-seefahrt vom 21 Juli bis 9 September, 1872, 1. Rhizopoden. 11 Kommission für Untersuchungen der Deutschen Meere in Kiel, Jahreberichte, 1872-73: 99-114.

Scott, G., Thompson, L., Hitchin, R. \& Scourse, J., 1998. Observations on selected salt-marsh and shallow-marine species of agglutinated foraminifera: grain size and mineralogical selectivity. Journal of Foraminiferal Research, 28: 261-267.

Stancliffe, R. P. W. 1989. Microforaminiferal linings: their classification, biostratigraphy and paleoecology, with special reference to specimens from British Oxfordian sediments. Micropaleontology, 35: 337-352.

Stewart, G. A. \& Lampe, L. 1947. Foraminifera from the Middle Devonian bone beds of Ohio. Journal of Paleontology, 21: 529-536.

Stewart, G. A. \& Priddy, R. R. 1941. Arenaceous foraminifera from the Niagaran Rocks of Ohio Indiana. Journal of Paleontology, 15: 366 375.

Talent, J. A. 1965. The stratigraphic and diastrophic evolution of central and eastern Victoria in Middle Palaeozoic times. Proceedings of the Royal Society of Victoria, 79: 175-195.

Talent, J. A. 1969. The Geology of East Gippsland. Proceedings of the Royal Society of Victoria, 82: 37-60.

Toomey, D. F. 1974. The biota of the Pennsylvanian (Virgilian) Leavenworth Limestone, Midcontinent region. Part 4: distribution of agglutinated and siliceous foraminifera. Journal of Paleontology, 48: $326-343$

Wilson, G. A. 1989. Documentation of conodont assemblages across the Lochkovian-Pragian (early Devonian) boundary at Wellington, central New South Wales, Australia. Senckenbergiana Courier, 117: $117-171$.

Winchester-Seeto, T. 1993a. Expanded biostratigraphic perspectives for Devonian Chitinozoa. Memoirs of the Association of Australasian Palaeontologists, 9: 249-254.

Winchester-Seeto, T. 1993b. Chitinozoa from the Early Devonian (Lochkovian-Pragian) Garra Limestone, central New South Wales, Australia. Journal of Paleontology, 67: 738-758.

Winchester-Seeto, T. 1993c. Chitinozoan assemblages from the Pragian (Lower Devonian) of eastern Australia. Proceedings of the Royal Society of Victoria, 105: 85-112.

Winchester-Seeto, T. 1996. Emsian Chitinozoa from the Buchan area of southeastern Australia. Acta Palaeontologica Polonica, 41: 149-230.

Winchester-Seeto, T. \& Bell, K. N. 1994. Microforaminiferal linings from the Early Devonian of eastern Australia and their generic placement. Journal of Paleontology, 68: 200-207.

Winchester-Seeto, \& Paris, F. 1995. Late Givetian and Frasnian chitinozoans from Australia, France and Pakistan in relation to conodont zonation. Courier Forschungsinstitut Senckenberg, 182: 451473.

Wyatt, D. H. \& Jell, J. S. 1980. Devonian and Carboniferous stratigraphy of the northern Tasman Orogenic Zone in Townsville hinteriand, north Queensland. In: Henderson, R. A. \& Stephenson, P. J. (eds), The Geology and Geophysics of Northeastern Australia. Geological Society of Australia, Queensland Division, Brisbane, 201208.

Yolkin, E. A, Gratsianova, R. T. \& 6 others 1988. Facies and faunal associations of the Telengitian (Emsian) in its type locality. Canadian Society of Petroleum Geologists, 1988, III: 193-205. 